\title{
Microanalysis of Metal-Accumulating Biomolecules
}

\author{
M. Farina, C.N. Keim, J.D. Corrêa Jr., and L.R. Andrade \\ Universidade Federal do Rio de Janeiro, Inst. Ciências Biomédicas, RJ, 21941-590, Brazil.
}

Several organisms, from bacteria to higher animals, are capable to accumulate different cations, including heavy metals from the environment. The molecular assemblies responsible for metal binding may be various. In this work, we describe phosphorus-rich granules from bacteria and a marine invertebrate, and polyanionic polysaccharides from the cell wall of a brown alga as the metal binding structures. Calcium and magnesium carbonates and phosphate granules are present intra and extra-cellularly in many invertebrates. Carbonate granules have been associated to calcification and acid-base control, while the role of phosphate granules is yet not completely known [1]. Phosphorus-rich granules may contain orthophosphate $\left(\mathrm{PO}_{4}{ }^{3-}\right)$, pyrophosphate $\left(\mathrm{P}_{2} \mathrm{O}_{7}{ }^{4-}\right)$, and polyphosphates (chains of tetrahedral $\mathrm{PO}_{4}$ units). The ions of the alkaline earth metals may be partially covalently bounded or at least are held at specific sites in the complexes, and this would account for the immobilization of heavy metals in the granules [2].

Many uncultured bacteria contain polyphosphate granules, which are frequently lost after repeated culturing in laboratory medium. Among these organisms are several morphotypes of magnetotactic bacteria [3]. Using magnetotactic bacteria as a model for studying metal accumulation in uncultured microorganisms is interesting as they present intracellular compartmentalization of biominerals (e.g. the magnetosomes and the phosphorus-rich granules) [3]. Figure 1 shows that Mn accumulated in the polyphosphate granules when uncultured magnetotactic bacteria were exposed to $\mathrm{MnCl}_{2}$.

We have studied phosphate-rich granules from the hepatopancreas of the terrestrial crab Ucides cordatus [4]. Granules had circa of $1 \mu \mathrm{m}$ in diameter and contained mainly $\mathrm{P}$ and $\mathrm{Ca}$ and contaminant cations like Mn when in vitro experiments are performed (Figure 2). NMR based on

${ }^{31} \mathrm{P}$ (not shown) showed that water suspensions containing isolated mineral granules present mainly dissolved ortophosphate in the liquid phase.

The brown alga Padina gymnospora precipitates heavy metals along the cell walls in in vitro assays using $\mathrm{Zn}$ and $\mathrm{Cd}$ in seawater [5]. Deposits containing $\mathrm{Zn}$ were found in algae from contaminated sites [5]. The cell wall of this alga contains polyanionic polysaccharides formed by alginates (rich in carboxyl groups) and fucans (rich in sulphate groups) that play an important role in metal binding. Figure 3 shows a self-assembled aggregate of the isolated polysaccharides total fraction from the cell wall of $P$. gymnospora collected in an environment contaminated by $\mathrm{Zn}$, near Rio de Janeiro city. $\mathrm{Zn}$ was found in the extracted polysaccharides fraction even after procedures for their isolation were performed, confirming the high affinity of these compounds to metal cations.

In conclusion, controlled in vitro experiments with phosphorus-rich granules and polyanionic polysaccharides from $P$. gymnospora cell wall confirm that these biomolecules may play a role in biological survival of the organisms in metal contaminated sites.

\section{References:}


[1] A.P. Lee et al., Proc. R. Soc. Lond. B. 261 (1995) 263.

[2] F. Rashchi and J.A. Finch., Minerals Engineering 1(2000) 1035.

[3] Keim, C.N. et al., Can. J. Microbiol. 47 (2001) 1132.

[4] J.D. Corrêa Junior et al., Tissue \& Cell 34 (2003) 315.

[5] L.R. Andrade et al., Phycologia 41 (2002) 39.

[6] Financial Support: CNPq and Faperj Brazilian Agencies.
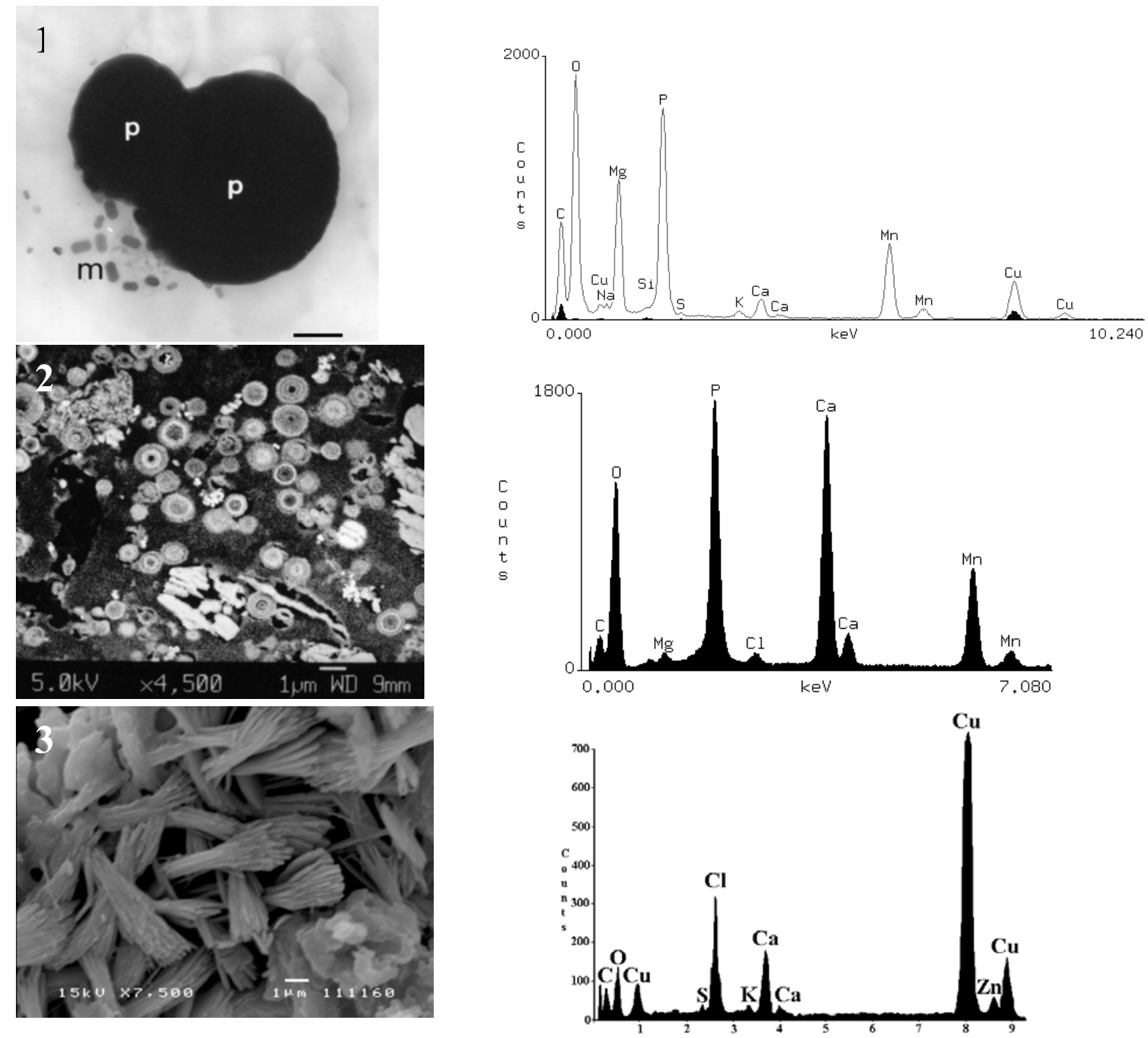

Figure 1: Magnetotactic bacteria subjected to $\mathrm{MnCl}_{2}$. $\mathrm{Mn}$ is confirmed in polyphosphate granules (PG) by EDS (continuous line). Dark spectrum- cytoplasm; m- magnetosomes; p- PG; Bar $=0.25$ $\mu \mathrm{m}$.

Figure 2: Section of isolated phosphorus-rich granules from U. cordatus hepatopancreas observed with back-scattered electrons. Note rings of mineral deposition. EDS spectrum of a contaminated granule presents $\mathrm{Mn} . \mathrm{Bar}=1 \mu \mathrm{m}$.

Figure 3: Polyanionic polysaccharides isolated from algae collected at a contaminated site. EDS spectrum shows the presence of $\mathrm{Zn}$ in the sample. $\mathrm{Bar}=0.5 \mu \mathrm{m}$. 